\title{
Development and Characterization of Novel Biopolymer Derived from Abelmoschus esculentus L. Extract and Its Antidiabetic Potential
}

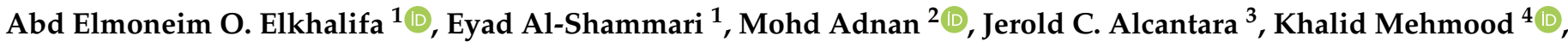 \\ Nagat Elzein Eltoum ${ }^{1}$, Amir Mahgoub Awadelkareem ${ }^{1}$, Mushtaq Ahmad Khan ${ }^{5}$ and Syed Amir Ashraf ${ }^{1, *}$ \\ check for \\ updates \\ 1 Department of Clinical Nutrition, College of Applied Medical Sciences, University of Hail, \\ Hail P.O. Box 2440, Saudi Arabia; ao.abdalla@uoh.edu.sa (A.E.O.E.); eyadhealth@hotmail.com (E.A.-S.); \\ nagacademic0509@gmail.com (N.E.E.); mahgoubamir22@gmail.com (A.M.A.) \\ 2 Department of Biology, College of Science, University of Hail, Hail P.O. Box 2440, Saudi Arabia; \\ drmohdadnan@gmail.com \\ 3 Department of Clinical Laboratory Sciences, College of Applied Medical Sciences, University of Hail, \\ Hail P.O. Box 2240, Saudi Arabia; jerold.alcantara@yahoo.com \\ 4 Department of Pharmaceutics, College of Pharmacy, University of Hail, Hail P.O. Box 81481, Saudi Arabia; \\ adckhalid@gmail.com \\ 5 Department of Microbiology and Immunology, College of Medicine and Health Sciences, UAE University, \\ Al Ain 15551, United Arab Emirates; mushtaq.khan@uaeu.ac.ae \\ * Correspondence: s.amir@uoh.edu.sa or amirashrafy2007@gmail.com; Tel.: +966-591491521 or +966-165358298
}

Citation: Elkhalifa, A.E.O.;

Al-Shammari, E.; Adnan, M.;

Alcantara, J.C.; Mehmood, K.; Eltoum, N.E.; Awadelkareem, A.M.; Khan,

M.A.; Ashraf, S.A. Development and

Characterization of Novel

Biopolymer Derived from

Abelmoschus esculentus L. Extract and Its Antidiabetic Potential. Molecules

2021, 26, 3609. https://doi.org/

$10.3390 /$ molecules26123609

Academic Editors: Severina Pacifico and Simona Piccolella

Received: 30 March 2021

Accepted: 9 June 2021

Published: 12 June 2021

Publisher's Note: MDPI stays neutral with regard to jurisdictional claims in published maps and institutional affiliations.

Copyright: (c) 2021 by the authors. Licensee MDPI, Basel, Switzerland. This article is an open access article distributed under the terms and conditions of the Creative Commons Attribution (CC BY) license (https:/ / creativecommons.org/licenses/by/ $4.0 /)$.
Abstract: Abelmoschus esculentus (Okra) is an important vegetable crop, widely cultivated around the world due to its high nutritional significance along with several health benefits. Different parts of okra including its mucilage have been currently studied for its role in various therapeutic applications. Therefore, we aimed to develop and characterize the okra mucilage biopolymer (OMB) for its physicochemical properties as well as to evaluate its in vitro antidiabetic activity. The characterization of OMB using Fourier-transform infrared spectroscopy (FT-IR) revealed that okra mucilage containing polysaccharides lies in the bandwidth of 3279 and $1030 \mathrm{~cm}^{-1}$, which constitutes the fingerprint region of the spectrum. In addition, physicochemical parameters such as percentage yield, percentage solubility, and swelling index were found to be $2.66 \%, 96.9 \%$, and 5 , respectively. A mineral analysis of newly developed biopolymers showed a substantial amount of calcium (412 mg/100 g), potassium (418 mg/100 g), phosphorus $(60 \mathrm{mg} / 100 \mathrm{~g})$, iron $(47 \mathrm{mg} / 100 \mathrm{~g})$, zinc $(16 \mathrm{mg} / 100 \mathrm{~g})$, and sodium $(9 \mathrm{mg} / 100 \mathrm{~g})$. The significant antidiabetic potential of OMB was demonstrated using $\alpha$-amylase and $\alpha$-glucosidase enzyme inhibitory assay. Further investigations are required to explore the newly developed biopolymer for its toxicity, efficacy, and its possible utilization in food, nutraceutical, as well as pharmaceutical industries.

Keywords: okra mucilage; okra polysaccharides; biopolymer; $\alpha$-amylase activity; $\alpha$-glucosidase activity; nutraceuticals; antidiabetic activity

\section{Introduction}

Abelmoschus esculentus (L.) Moench is a popular vegetable crop cultivated throughout the world mostly in tropical and subtropical regions. The cultivation of okra vegetable is globally known for its palatability [1]. Okra plant and its derived products have been studied for various therapeutic purposes, such as antidiabetic, antioxidant, anticancer, immunomodulatory potentials, as well as its ability to ease constipation [1]. Currently, the mucilage or latex present in okra has drawn attention of the scientific community for its application as an intervention for new therapeutic purposes, as the infusion of okra mucilage has been earlier used in traditional Indian ethnomedicine for treating dysentery, diarrhea, and many more [2]. Previous studies indicated that okra mucilage could have a potential 
role in the management of diabetes [3]. Mucilaginous substances present in the pod walls of okra containing significant amount of protein, carbohydrate, neutral sugars, minerals, and other complex polysaccharides [4,5]. Polysaccharides are a very important class of biopolymers and represent a structurally diverse class of macromolecules. Furthermore, natural polymers derived from plant or animal sources have high molecular weight along with increased polarity, as these polymers are made up of monosaccharide units and joined by glycosides linkage [6]. Moreover, polysaccharides are highly diverse in structure and biological functions including serving as structural components of cell walls, cell recognition, cell proliferation, energy storage, cell differentiation, regulation of signaling, and immune responses [7]. This enormous potential variability in polysaccharide structure gives the necessary flexibility for the precise regulatory mechanisms of various cell-cell interactions in higher organisms. Recent research is focused on polysaccharides isolated from natural sources, because of its low side effect or with minimal toxicity. Meanwhile, several naturally occurring polysaccharides such as cellulose, starch, pectin, acacia gum, gum arabic, arabinogalactan, xylan, beta-glucan, and karaya gum has been reported $[8,9]$. Furthermore, the main bioactive component of okra mucilage is okra polysaccharide, which is reported to be comprising of pectic polysaccharides [10]. Meanwhile, the compositions of waterextractable polysaccharides were reported to be galacturonic acid, rhamnose, arabinose, xylose, mannose, galactose, glucose, xylan, starch, and uronic acid [11,12]. In addition, okra polysaccharides have been reported for their antioxidant activity, immunomodulatory activity, ability to improve metabolic disorders and intestinal function, hypoglycemic activity, and antifatigue activities. Rhamnogalacturonan, a polysaccharide extracted from okra, has been reported to have an antidiabetic effect [11].

Okra polysaccharides have been seen as a promising bioactive component considering its future prospective in food and pharmaceutical purposes for the development of novel polymer $[10,11,13,14]$. Additionally, okra polysaccharides could also become a source for the development of antidiabetic biopolymer, since it is considered to be very economical, non-toxic, and biodegradable [6]. Diabetes is currently one of the most prevalent epidemics worldwide; it represents an increase in socioeconomic burden, affecting about 382 million people globally, and each year, around 1.3 million people die from diabetes. By 2045, an estimate of 629 million people will be diabetic worldwide, as reported by the International Diabetes Federation in 2017 [15]. Moreover, the etiology of different types of diabetes varies, but complications related to high blood glucose are common in both types of diabetes. Meanwhile, drug or diet ability to delay the production or absorption of glucose by inhibiting carbohydrate-hydrolyzing enzymes such as $\alpha$-amylase and $\alpha$-glucosidase is one of the most common therapeutic approaches used for the treatment of hyperglycemia [16]. Additionally, $\alpha$-glucosidase inhibitors are considered to be more effective categories of antidiabetic agents used in hyperglycemia, especially in case of postprandial hyperglycemia over $\alpha$-amylase inhibitors. The membrane bound $\alpha$-glucosidase enzymes speed up the digestion of oligosaccharides and disaccharides into simple monosaccharides, after which they get absorbed and enter into the bloodstream. The inhibition of $\alpha$-glucosidase as well as $\alpha$-amylases enzyme can help in delaying the digestion of carbohydrates, thereby reducing the levels of glucose in blood [17]. At present, the use of carbohydrate digesting enzyme inhibitors plays a vital role in controlling hyperglycemia by reducing the intestinal absorption of glucose [16].

However, several reports suggest that pharmacological agents are usually associated with some side effects, adverse effects, and even sometimes, their efficacies are controversial. Hence, attention has been shifted toward traditional and alternative medicines or foodderived products rich in antidiabetic phytoconstituents. The bioactive components present in plants and plants derived products such as alkaloids, flavonoids, glycosides, gum, carbohydrates, triterpenes, and different types of peptides are usually responsible for their therapeutic importance [18-21]. Recently, okra has been recognized for its potential therapeutic purposes due to the presence of various important phytochemicals including polysaccharides $[1,22]$. Therefore, despite having various therapeutic applications of okra 
fruits, seeds, pods, its mucilage has not been much explored toward its promising potential. Hence, a novel biopolymer derived from okra mucilage has been developed along with its physicochemical characterization, and its antidiabetic properties are studied.

\section{Results and Discussion}

\subsection{Characterization of Okra Mucilage Biopolymer by FT-IR}

Okra mucilage biopolymer (OMB) characterization using FT-IR analysis identifies several functional groups representing characteristic bands of polysaccharides lying between 3279 and $1030 \mathrm{~cm}^{-1}$, which constitute the fingerprint region of the spectrum, as presented in Figure 1. The broad band at $3279 \mathrm{~cm}^{-1}$ is mainly due to the presence of hydrogen-bonded hydroxyl groups, which give rise to the complex vibrational bands associated with free intermolecular and intramolecular bound hydroxyl groups, which leads to the gross structure of carbohydrates [23,24]. Our FT-IR data also revealed the characteristic of polysaccharide consisting of galactose, rhamnose, and galacturonic acid represented by the broad-spectrum peak at $3279 \mathrm{~cm}^{-1}$, suggesting the presence of aromatic sugar with $\mathrm{O}-\mathrm{H}$ as the principle functional groups. Meanwhile, the presence of an $\mathrm{O}-\mathrm{H}$ functional group in the broad peak characterizes hydrophilic nature of the polysaccharides. The hydroxyl groups in carbohydrate have intermolecular and intramolecular hydrogen bonding that give broad band at $3279 \mathrm{~cm}^{-1}$ [24]. In addition, the band present at $2938 \mathrm{~cm}^{-1}$ is also a characteristic of methyl $\mathrm{C}-\mathrm{H}$ bonding associated with benzene rings. In cellulose and hemicellulose components, the characteristic $\mathrm{C}-\mathrm{H}$ stretching corresponds to the band at $2942 \mathrm{~cm}^{-1}$ [25]. In complex polysaccharides spectra, $1245 \mathrm{~cm}^{-1}$ was assigned for the $\mathrm{C}-\mathrm{O}$ stretching band, whereas $1030 \mathrm{~cm}^{-1}$ was assigned for the $\mathrm{C}-\mathrm{O}-\mathrm{C}$ group, indicating the presence of aromatic bonds present in galactose, galacturonic acid, as well as in rhamnose.

The amide I band corresponds to the band at $1625 \mathrm{~cm}^{-1}$, which comes in the most sensitive spectral region, depicting the secondary organizational units of proteins [26]. This band is purely due to peptide linkages and CO stretch vibrations, indicating the presence of protein. As the biopolymer was not subject to deproteinization, the protein bands were observed [27]. The absorption at $1732 \mathrm{~cm}^{-1}$ was observed because of ester carbonyl, which has also been reported in a previous study on okra mucilage [28]. Moreover, the presence of carbonyl, methyl, as well as hydroxyl functional groups in okra are representative of polysaccharides molecules, which is considered to be the backbone of the developed polymer. Our results confirmed that OMB is composed of polysaccharides. However, the polysaccharides were not in the form of cellulose or starch, but few functional bands indicated the presence of peptide cross-link along with some amino sugars, and our results are in line with earlier studies [24,29].

\subsection{Percentage Yield, Solubility, and Swelling Index of Okra Mucilage Biopolymer}

Okra mucilage extraction and its percentage yield were found to be $2.66 \% w / w$ using water as the extraction liquid, and according to previous studies, the percentage yield of okra mucilage was reported to range from $0.5 \%$ to $11 \%$ [28,30,31]. These variations in the percentage yield of okra mucilage could be due to several factors, such as the physical state of pods (dried or hydrated), cultivation region of pods, breed of okra, parts of okra (crown or pulp), and maturation state of okra pods. In addition, the percentage yield could also be affected by the extraction method used [25]. It has been reported that acetone is more effective when compared to methanol as an extraction solvent; the yield rises by 31 times [28]. Percentage yield was recorded on a dry weight basis, and the moisture content of extracted mucilage was found to be $9.6 \%$. Currently, scientific communities are working more on these factors to determine the optimal conditions of mucilage extraction, such as extraction time, temperature, extraction cycle number, and raw material-to-solvent ratio. Okra mucilage extraction by the water extraction method gave the yield of $2.66 \%$, and the conditions were temperature of $70^{\circ} \mathrm{C}$ for $2 \mathrm{~h}$ and agitating at $200 \mathrm{rpm}$ [32]. The solution obtained was caramel-colored, viscous, and slippery. We found that the solubility of extracted mucilage polymer at neutral $\mathrm{pH}$ was $96.9 \%$. Earlier studies have also indicated 
that okra mucilage is partially soluble in cold water and soluble in warm water. Our results are also consistent with the previous reported studies. All the characteristics obtained were similar to those reported previously [31,33].

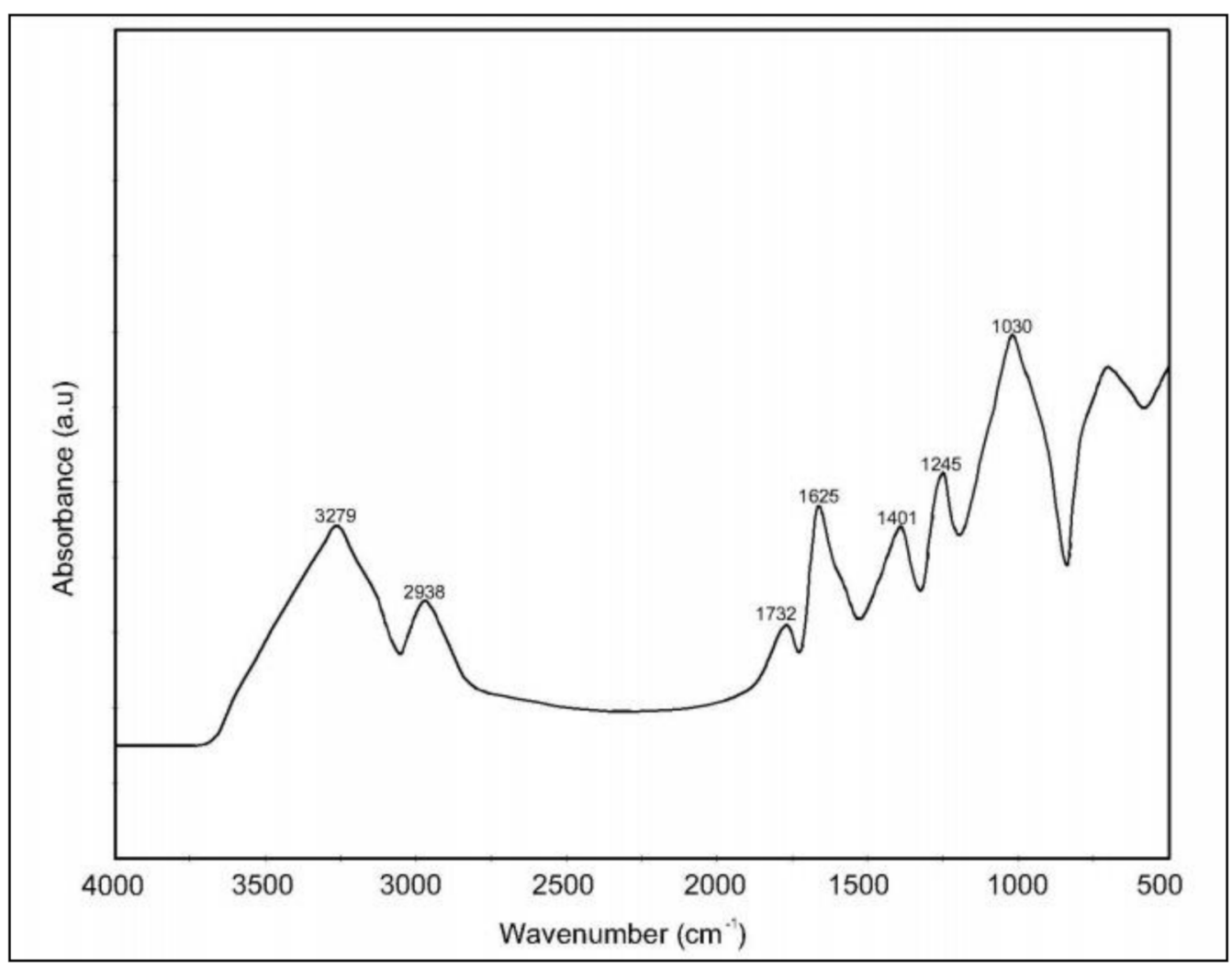

Figure 1. FT-IR spectrum of okra mucilage.

Additionally, we found that the swelling index of $\mathrm{OMB}$ at $\mathrm{pH} 7.5$ in deionized water was 5.0. Moreover, the swelling index has been found to be increasing with a gradual increase of $\mathrm{pH}$, as presented in Figure 2. This increase in the swelling index of okra mucilage could be due to its increase in intra-ionic repulson when the ionization of carboxyl groups $(-\mathrm{COOH})$ is high. In addition, we also found that at $\mathrm{pH} 5.5$, the swelling index was the lowest; this could be due to the low ionization of the major functional groups present in mucilage biopolymer. The $\mathrm{pH}$-responsive behavior shown by OMB could present a favorable condition for the controlled release of a bioactive active component in pharmaceutical as well as nutraceutical industries [24]. In addition, the controlled release of active agents at different $\mathrm{pH}$ indicates a unique polymer behavior, which is indispensable in the packaging of food. Earlier studies have indicated that the polymer prepared for drug development shows reduced swelling onwards of $\mathrm{pH}>7.4$, which could be due to carboxyl groups ionization, and polymer dissolution occurs [34]. However, further studies are required for a better analysis of this reported behavior. 


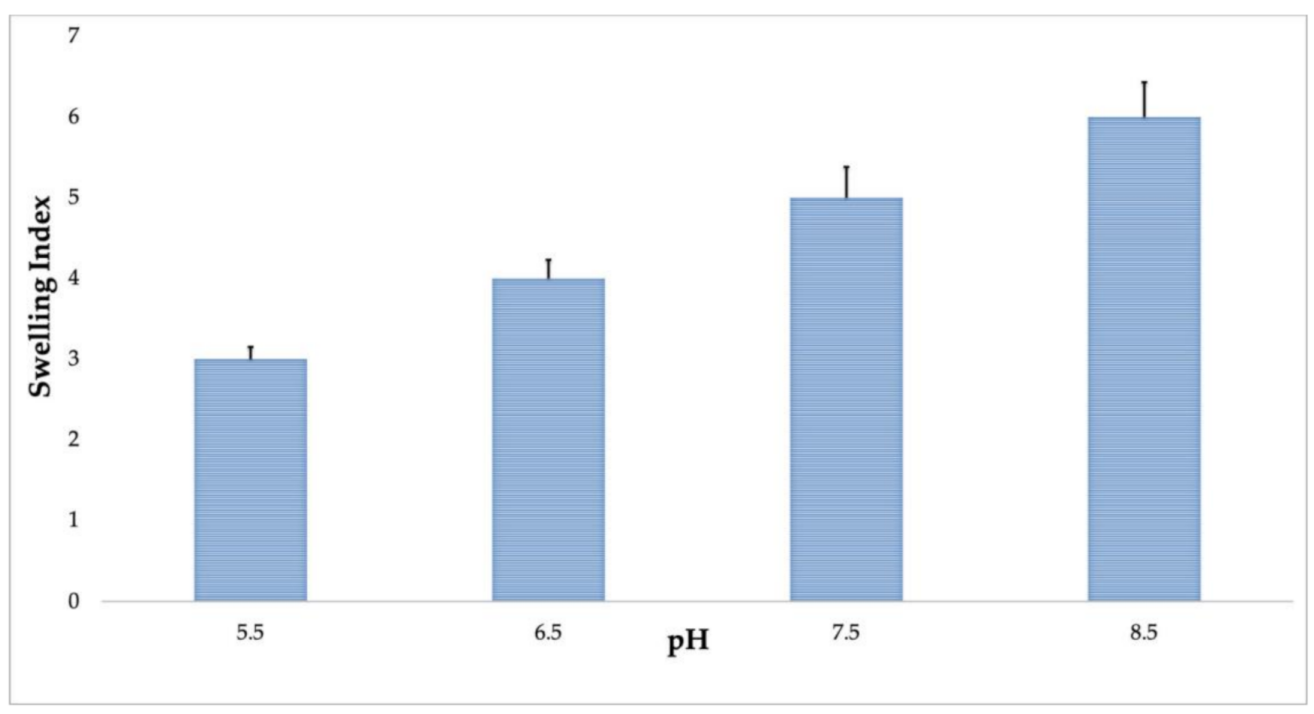

Figure 2. Swelling index of okra mucilage biopolymer at different $\mathrm{pH}$. All experiments were performed in triplicate, and data represent mean \pm standard deviation.

\subsection{Mineral Composition}

Minerals are considered as one of the important parts of human nutrition, which help to promote a healthy physical and mental state. The minerals are the principal elements of the bones, teeth, tissues, muscles, blood, and nerve cells [35]. They play an important role in acid-base balance maintenance, nerve response to physiological stimulation, and in the clotting of blood [36]. The major component of bone is calcium, which is essential in teeth development, blood coagulation, and intracellular cement substance integrity [37]. The mineral constitution of OMB is summarized in Figure 3. The calcium concentration of OMB was found to be $412 \mathrm{mg} / 100 \mathrm{~g}$. One of the key trace elements required is iron, which is helpful in the synthesis of hemoglobin, central nervous system functioning, and oxidation of carbohydrates, fats, and proteins [38,39], which is further important in preventing diabetes. The low iron content in the body leads to infection in the gastrointestinal pathway, epistaxis (nose bleeding), and myocardial infection [40]. Figure 3 presents the iron content of $\mathrm{OMB}$, which was found to be $47 \mathrm{mg} / 100 \mathrm{~g}$. Zinc is another required trace element having important roles in many cellular processes such as normal body growth, development of the brain, behavioral responses, formation of bone, and smooth wound healing [41]. Protein and carbohydrate metabolism requires zinc. The hepatic stellate cells (HSCs) of the liver are the storage sites of vitamin A, and zinc is involved in its mobility to other body parts from the liver. Zinc metalloenzymes are involved in DNA and RNA biosynthesis [42]. The deficiency of zinc is commonly seen in people suffering from Crohn's disease, hypothyroidism, and gum disease (Periodontitis). People with zinc inadequacy are vulnerable to viral infections and diabetes mellitus. Zinc plays a favorable role in treating viral infections such as AIDS, prostate gland enlargement, rheumatoid arthritis, laceration, acne, eczema, and stress [43]. Figure 3 presents the zinc content of OMB, which was found to be $16.31 \mathrm{mg} / 100 \mathrm{~g}$. Other minerals detected in okra mucilage in significant amount were phosphorus (60 mg/100 g), potassium ( $418 \mathrm{mg} / 100 \mathrm{~g})$, and sodium $(9 \mathrm{mg} / 100 \mathrm{~g})$. A high potassium level in the body causes an increased utilization of iron in the body. Potassium is also beneficial to patients administered with diuretics for hypertension control and those having excessive potassium excretion via body fluid [44]. 


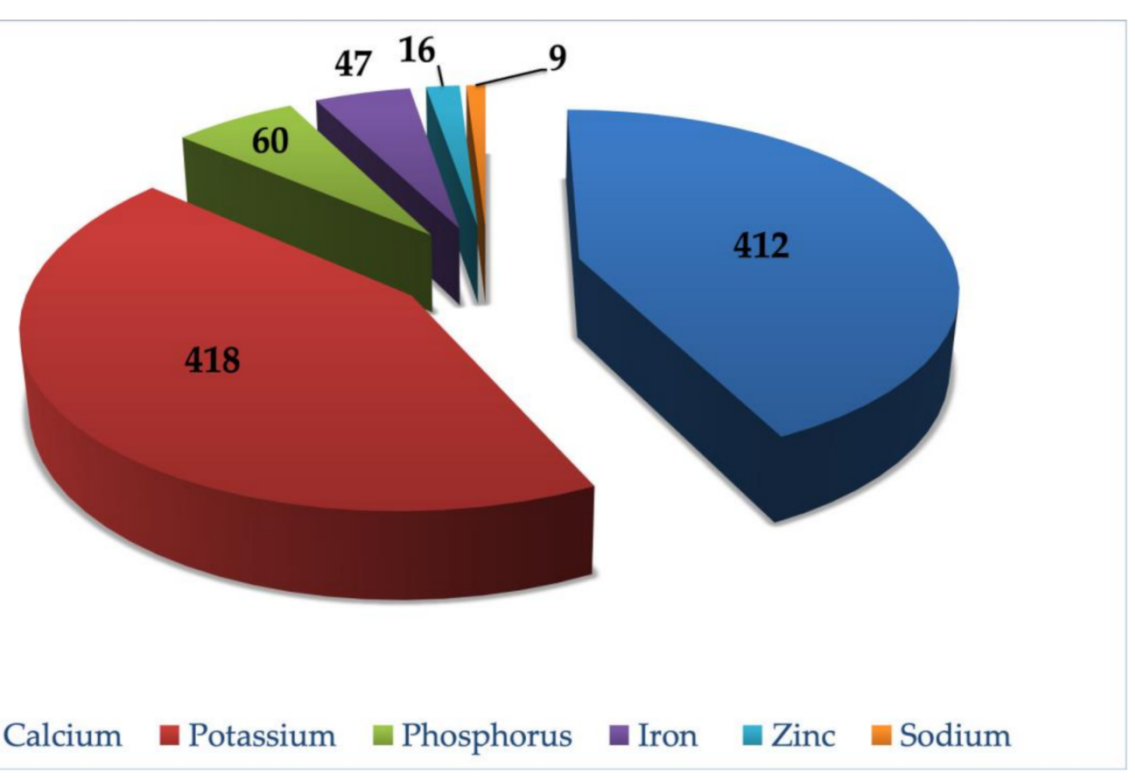

Figure 3. Mineral contents (mg/100 g) of okra mucilage biopolymer.

\subsection{Antidiabetic Activity}

The use of plant-based approaches in the existing modern medications system for the treatment of chronic disease such as diabetes is gaining recognition. Majorly, two of the $\alpha$-amylase and $\alpha$-glucosidase enzymes are considered to be responsible for diabetic conditions: $\alpha$-amylase begins the process of carbohydrate digestion by hydrolysis of 1, 4-glycosidic linkages of polysaccharides (starch, glycogen) to disaccharides, and $\alpha$ glucosidase catalyzes the disaccharides to monosaccharides, which leads to postprandial hyperglycemia. Hence, inhibitors of $\alpha$-amylase and $\alpha$-glucosidase are useful for the control of high glucose level, as they delay carbohydrate digestion, which consequently reduces the postprandial plasma glucose level [16].

To study the antidiabetic activity of $\mathrm{OMB}, \alpha$-amylase enzyme assay (Figure $4 \mathrm{a}$ ) and $\alpha$-glucosidase inhibitory assay (Figure $4 b$ ) were performed. The $\alpha$-amylase inhibition enzyme assay of okra mucilage revealed that the new developed okra biopolymer had significant anti-diabetic property with the increase in the concentration of biopolymer, and its inhibitory activity was highest. On the other hand, $\alpha$-glucosidase inhibitory assay showed that OMB had concentration-dependent inhibitory effects. The mucilage biopolymer at different concentration of $1,2,3,4$, and $5 \mathrm{mg} / \mathrm{mL}$ showed 9.9, 16.5, 24.5, 28.2, and $49.8 \alpha$-amylase inhibitory activity as well as 30, 41.5, 50.5, 62.2, and $69.7 \alpha$-glucosidase inhibitory activity, respectively. Figure $4 \mathrm{a}, \mathrm{b}$ showed that the higher the concentration, the higher the inhibition of $\alpha$-amylase and $\alpha$-glucosidase inhibition. This could be due to high concentrations representing more solutes in the form of secondary metabolites from okra polymer, which had the ability to inhibit the action of both antidiabetic enzymes.

Earlier, the antidiabetic activity of okra has been reported by Ahmad et al. (2016), and they found that aqueous extract of okra at different increasing concentrations (50, $100,150,200$, and $250 \mu \mathrm{g} / \mathrm{mL}$ ) has reportedly increased the inhibition for both percentage of $\alpha$-amylase and $\alpha$-glucosidase enzyme. This reported result was consistent with our results $[45,46]$. In both the assays, the mucilage polymer showed significant results, indicating that $\mathrm{OMB}$ has potential, and it needs to be further explored for toxicity studies and clinical trials, and by virtue of that, it could become an important anti-diabetic agent. 


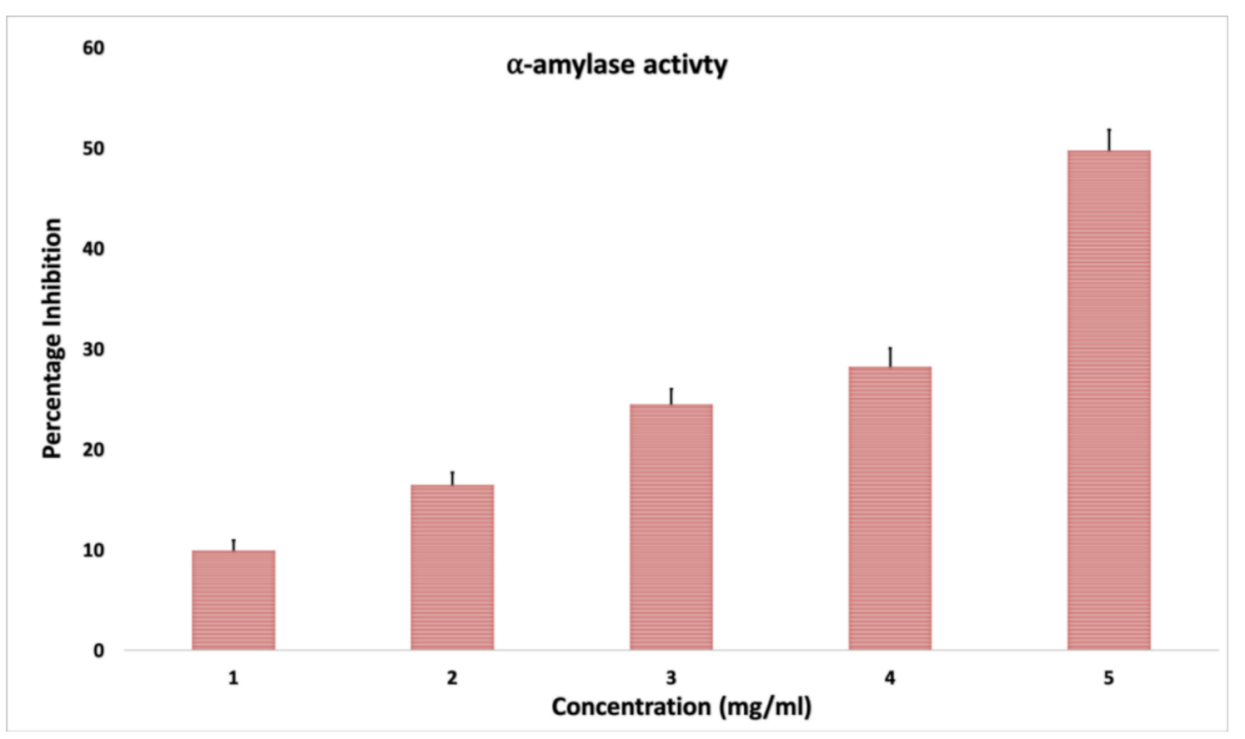

(a)

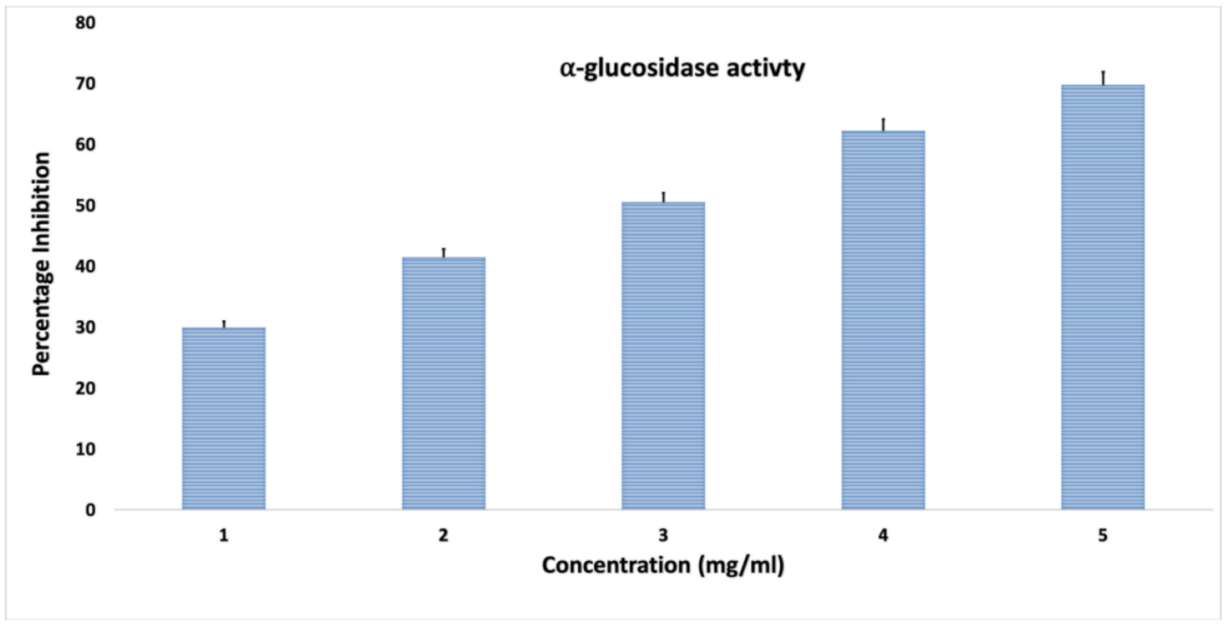

(b)

Figure 4. Screening of (a) $\alpha$-amylase inhibitory assay, (b) $\alpha$-glucosidase inhibitory assay of okra mucilage biopolymer at various concentrations. All experiments were performed in triplicate, and data are expressed as mean \pm standard deviation.

\section{Materials and Methods}

\subsection{Materials}

Mature okra pods were collected during the month of September 2020 from the local markets of Hail city, Saudi Arabia. Samples collected from the local market were carefully assorted, cleaned, washed from the earthy or waste material, and further dried under the shade for 1 day. The kits used for $\alpha$-amylase enzyme, $\alpha$-glucosidase inhibitory assays, and ethanol was bought from Sigma-Aldrich ${ }^{\circledR}$ (St. Louis, MO, USA). No additional purification was done in these kits before using them for the experiments. All other reagents used to carry out the experiments in this study were of analytical grade.

\subsection{Extraction of Okra Mucilage}

The okra pods were sliced, deseeded, and then water-soaked at ambient temperature. Liquid fraction or filtrate was separated from the solid content after $12 \mathrm{~h}$ using a muslin cloth. To the filtrate, triple the volume of ethanol was added. The liquid was stirred slowly by hand until the mucilage was fully precipitated. The mucilage was left to dry in an oven for about $12 \mathrm{~h}$ at $30^{\circ} \mathrm{C}$. Later, the dried mucilage was ground into powdered form evenly 
using a grinder and then passed through sieves. The finely pulverized polymer was kept in polyethylene pouch bags in the dark until further analyses [47].

\subsection{Characterization of Okra Mucilage Biopolymer}

The FT-IR experiments were carried out using the Thermo Scientific ${ }^{\circledR}$ Nicolet TM 6700 FT-IR spectrophotometer. The attenuated total reflection was performed to obtain the spectra. In this technique, Zn-Se crystals were used to press the samples, and $4000-650 \mathrm{~cm}^{-1}$ was the range of collection. An average of 16 scans having a resolution of $4 \mathrm{~cm}^{-1}$ was considered.

\subsection{Quantitative Yield Determination}

The percentage yield was calculated by the previously reported method of Jouki et al. $(2014)[48,49]$. The weight of okra pods without seeds in grams $\left(m_{s}\right)$ was used to calculate the yield. After the extraction, the weight of mucilage polymer was converted into milligrams (m). The percentage yield was calculated using Equation (1) as mentioned below.

$$
\text { Yield }=\frac{\mathrm{m}}{\mathrm{m}_{\mathrm{s}}}
$$

\subsection{Swelling Index}

The swelling index (SI) was determined according to the method reported by Cotrim et al. (2016) with certain modifications. In a graduated cylinder of $10 \mathrm{~mL}, 0.1 \mathrm{~g}$ of okra mucilage biopolymer was transferred. After measuring the initial dried sample volume, ionized water was added, and a final volume of $10 \mathrm{~mL}$ was made. The mucilage polymer swelled up to form a viscous gel. After $24 \mathrm{~h}$, the volume of swelled up mucilage was measured. The swelling index was calculated using Equation (2) mentioned below [49].

$$
\mathrm{SI}=\frac{\mathrm{V}_{\mathrm{f}}}{\mathrm{V}_{\mathrm{b}}}
$$

where $V_{f}=$ final volume $24 \mathrm{~h}$ later, and $V_{b}=$ dry mucilage initial volume.

\subsection{Solubility of Okra Mucilage Biopolymer}

Dry okra mucilage biopolymer $(0.1 \mathrm{~g})$ was taken in a graduated cylinder of $10 \mathrm{~mL}$ to study its solubility in water. Deionized water was added to make the volume up to $10 \mathrm{~mL}$, and the sample solutions were left for $6 \mathrm{~h}$. Furthermore, the dispersed samples were subjected to magnetic stirring at $60^{\circ} \mathrm{C}$ for $1 \mathrm{~h}$. Later on, the sample solution was centrifuged at $4000 \mathrm{rpm}$ for $30 \mathrm{~min}$. After the centrifugation process, the insoluble matrix was separated and dried at $105^{\circ} \mathrm{C}$ until it achieved constant weight. The solubility percentage of the sample was obtained as per Equation (3), as mentioned below [31]

$$
\mathrm{S}=\frac{\mathrm{w}_{1}-\mathrm{w}_{2}}{\mathrm{w}_{1}} \times 100
$$

where $\mathrm{S}=$ percentage solubility, $\mathrm{w}_{1}=$ initial mass of dry mucilage, and $\mathrm{w}_{2}=$ mass of insoluble dry matter obtained after centrifugation.

\subsection{Determination of Mineral Content}

The mineral analysis of OMB was carried out according to the procedure mentioned in the AOAC (2016). Additionally, sample preparation was made by taking $1 \mathrm{~g}$ of the pre-dried sample in crucible and burned over a hot plate followed by ashing inside the muffle furnace at $550{ }^{\circ} \mathrm{C}$. Once the sample cools down, it was mixed $20 \%$ supra pure nitric acid $(50 \mathrm{~mL})$ in an Erlenmeyer flask and heated at $70-85^{\circ} \mathrm{C}$ for $6 \mathrm{~h}$. Meanwhile, during the digestion of the sample, supra pure nitric acid was added intermittently to maintain the volume. Furthermore, the sample was filtered cool and the volume was made up to $100 \mathrm{~mL}$ in a volumetric flask using deionized water. Afterwards, the prepared samples 
were placed for analysis of selected elements [50]. The standard flame emission photometer (PerkinElmer, Waltham, MA, USA) was used to determine the concentrations of sodium $(\mathrm{Na})$ and potassium $(\mathrm{K})$ present in the okra mucilage. Phosphorus $(\mathrm{P})$ content was quantified by the vanadomolybdate method AOAC (2016). Atomic absorption spectrophotometer (PerkinElmer, Waltham, MA, USA) was used to measure calcium (Ca), iron (Fe), and zinc (Zn) concentrations [51].

\subsection{Antidiabetic Activity}

To investigate the in vitro antidiabetic activity, $\alpha$-amylase inhibitory assay and $\alpha$ glucosidase inhibitory assay were performed.

\subsection{1. $\alpha$-Amylase Inhibitory Assay}

$\alpha$-Amylase inhibitory activity of OMB was carried out as per the method presented by Oliviya et al. (2018) with slight modification. Non-identical aliquots of mucilage biopolymer $(1,2,3,4$, and $5 \mathrm{mg} / \mathrm{mL})$, were taken separately. Subsequently, $250 \mu \mathrm{L}$ of $0.02 \mathrm{~N}$ sodium phosphate buffer containing $\alpha$-amylase solution $(0.5 \mathrm{mg} / \mathrm{mL})$ was added to it. Starch solution $(1 \%, 250 \mu \mathrm{L})$ prepared in $0.02 \mathrm{M}$ sodium phosphate was added to the solution. The incubation of $10 \mathrm{~min}$ at $25{ }^{\circ} \mathrm{C}$ was provided to this mixture. With the addition of $500 \mu \mathrm{L}$ of dinitrosalicylic acid, the reaction was terminated. Then, it was kept for $5 \mathrm{~min}$ in a boiling water bath. Then, the solution was cooled down, and absorbance (Abs) was recorded at $540 \mathrm{~nm}$ [52]. Negative control was prepared using distilled water, and the percentage inhibition was calculated by using following formula [53].

$$
\% \text { Inhibition }=\frac{\text { Abs. }(540)_{\text {control }}-\text { Abs. }(540)_{\text {sample }}}{\text { Abs. }(540)_{\text {control }}} \times 100
$$

\subsection{2. $\alpha$-Glucosidase Inhibitory Assay}

$\alpha$-Glucosidase inhibitory activity of okra mucilage biopolymer was carried out as per the method presented by Oliviya et al. (2018) with slight modification. Pre-incubation of $100 \mu \mathrm{L}$ of glucosidase with $50 \mu \mathrm{L}$ at different concentration $(1,2,3,4,5 \mathrm{mg} / \mathrm{mL})$ of mucilage biopolymer extract were taken separately. To start the reaction, $50 \mu \mathrm{L}$ of $3.0 \mathrm{mM} \mathrm{P}-$ nitrophenyl- $\alpha$-D-glucopyranoside was added in $20 \mathrm{mM}$ phosphate buffer. The solution was incubated for $20 \mathrm{~min}$ at a temperature of $37^{\circ} \mathrm{C}$. At this stage, the reaction was terminated by adding $0.1 \mathrm{M}$ of $\mathrm{Na}_{2} \mathrm{CO}_{3}$. The absorbance was measured at $405 \mathrm{~nm}$ [52]. Negative control was prepared using distilled water, and the percentage inhibition was calculated by using the following formula [53].

$$
\% \text { Inhibition }=\frac{\text { Abs. }(405)_{\text {control }}-\text { Abs. }(405)_{\text {sample }}}{\text { Abs. }(405)_{\text {control }}} \times 100
$$

\subsection{Statistical Analysis}

The data of all the experiments were expressed as mean \pm standard deviation of triplicate measurements. All the analysis were carried out using IBM SPSS software version 23.0 (IBM Corp. Armonk, NY, USA).

\section{Conclusions}

Okra, an easily available nutritive vegetable crop, has been found very interesting in terms of mineral content. Mucilage present in okra has been found to be a rich source of polysaccharides. Our study showed that the newly developed biopolymer had key physicochemical characteristics. Key parameters such as swelling index, solubility, as well as mineral analysis indicated that the newly developed biopolymer could become a potential source for food and pharmaceutical industries as packaging materials (edible polymer), emulsion stabilizers, binding agent, water retention agent, thickeners, etc. The high swelling index of biopolymer at different $\mathrm{pH}$ could open the door of possibilities 
for the development of edible polymer as well as for the development of nutraceuticals by incorporating bioactive components. In addition, FT-IR analysis suggested that it contains polysaccharides majorly composed of galactose, rhamnose, and galacturonic acid. Furthermore, mucilage biopolymer was evaluated for in vitro antidiabetic activity, and both $\alpha$-amylase and $\alpha$-glucosidase inhibitory assay showed positive response against the okra mucilage biopolymer, indicating its possible application for the advancement of anti-diabetic agent. Therefore, based upon our results, we can conclude that the newly developed okra mucilage biopolymer is enriched with nutritional content as well as it could become an important natural source for various food, nutraceutical as well as pharmaceutical applications.

Author Contributions: Conceptualization, A.E.O.E., E.A.-S. and S.A.A.; methodology, M.A., J.C.A., K.M. and N.E.E.; validation, M.A., M.A.K. and S.A.A.; formal analysis, E.A.-S., M.A., J.C.A. and A.M.A.; investigation, S.A.A., M.A., M.A.K. and K.M.; data curation, K.M., A.E.O.E., S.A.A., N.E.E. and M.A.; writing-original draft preparation, S.A.A. and M.A.; writing-review and editing, A.E.O.E., M.A. and M.A.K.; visualization, K.M., A.M.A. and S.A.A.; supervision, M.A., A.E.O.E. and M.A.K.; project administration, S.A.A., A.E.O.E. and M.A. All authors have read and agreed to the published version of the manuscript.

Funding: This research has been funded by Scientific Research Deanship at University of Ha'il Saudi Arabia through project number RG-191333.

Institutional Review Board Statement: Not applicable.

Informed Consent Statement: Not applicable.

Data Availability Statement: All data generated or analyzed during this study are included in this article.

Conflicts of Interest: The authors declare no conflict of interest. The funders had no role in the design of the study; in the collection, analyses, or interpretation of data; in the writing of the manuscript, or in the decision to publish the results.

Sample Availability: Samples of the compounds are not available from the authors.

\section{References}

1. Elkhalifa, A.E.O.; Alshammari, E.; Adnan, M.; Alcantara, J.C.C.; Awadelkareem, A.M.; Eltoum, N.E.; Mehmood, K.; Panda, B.P.; Ashraf, S.A. Okra (Abelmoschus Esculentus) as a Potential Dietary Medicine with Nutraceutical Importance for Sustainable Health Applications. Molecules 2021, 26, 696. [CrossRef] [PubMed]

2. Roy, A.; Shrivastava, S.L.; Mandal, S.M. Functional properties of Okra Abelmoschus esculentus L. (Moench): Traditional claims and scientific evidences. Plant Sci. Today 2014, 1, 121-130. [CrossRef]

3. Khosrozadeh, M.; Heydari, N.; Abootalebi, M. The Effect of Abelmoschus Esculentus on Blood Levels of Glucose in Diabetes Mellitus. Iran. J. Med. Sci. 2016, 41, S63. [PubMed]

4. Ahiakpa, K. Mucilage Content of 21 Accessions of Okra (Abelmoschus spp L.). Scientia Agriulturae 2014, 2, 96-101. [CrossRef]

5. Gemede, H.F.; Ratta, N.; Haki, G.D.; Woldegiorgis, A.Z. Nutritional Quality and Health Benefits of Okra (Abelmoschus Esculentus): A Review. Glob. J. Med Res. 2014, 14. [CrossRef]

6. Pala, K. Synthesis, characterization of Okra mucilage as a potential new age therapeutic intervention. In MOL2NET, International Conference Series on Multidisciplinary Sciences; USINEWS-04: US-IN-EU Worldwide Science Workshop Series; University of Minnesota Duluth: Duluth, MN, USA, 2020. [CrossRef]

7. Wang, H.J.; Liu, Y.M.; Qi, Z.M.; Wang, S.Y.; Liu, S.X.; Li, X.; Xia, X.C. An Overview on Natural Polysaccharides with Antioxidant Properties. Curr. Med. Chem. 2013, 20, 2899-2913. [CrossRef]

8. Mohammed, A.S.A.; Naveed, M.; Jost, N. Polysaccharides; Classification, Chemical Properties, and Future Perspective Applications in Fields of Pharmacology and Biological Medicine (A Review of Current Applications and Upcoming Potentialities). J. Polym. Environ. 2021, 1-13. [CrossRef]

9. Li, Q.; Niu, Y.; Xing, P.; Wang, C. Bioactive polysaccharides from natural resources including Chinese medicinal herbs on tissue repair. Chin. Med. 2018, 13,1-11. [CrossRef]

10. Liao, Z.; Zhang, J.; Liu, B.; Yan, T.; Xu, F.; Xiao, F.; Wu, B.; Bi, K.; Jia, Y. Polysaccharide from Okra (Abelmoschus esculentus (L.) Moench) Improves Antioxidant Capacity via PI3K/AKT Pathways and Nrf2 Translocation in a Type 2 Diabetes Model. Molecules 2019, 24, 1906. [CrossRef]

11. Zhu, X.-M.; Xu, R.; Wang, H.; Chen, J.-Y.; Tu, Z.-C. Structural Properties, Bioactivities, and Applications of Polysaccharides from Okra [Abelmoschus esculentus (L.) Moench]: A Review. J. Agric. Food Chem. 2020, 68, 14091-14103. [CrossRef] 
12. Xu, K.; Guo, M.; Du, J. Molecular characteristics and rheological properties of water-extractable polysaccharides derived from okra (Abelmoschus esculentus L.). Int. J. Food Prop. 2017, 20, S899-S909. [CrossRef]

13. Gao, H.; Zhang, W.; Wang, B.; Hui, A.; Du, B.; Wang, T.; Meng, L.; Bian, H.; Wu, Z. Purification, characterization and anti-fatigue activity of polysaccharide fractions from okra (Abelmoschus esculentus (L.) Moench). Food Funct. 2018, 9, 1088-1101. [CrossRef] [PubMed]

14. Nie, X.-R.; Fu, Y.; Wu, D.-T.; Huang, T.-T.; Jiang, Q.; Zhao, L.; Zhang, Q.; Lin, D.-R.; Chen, H.; Qin, W. Ultrasonic-Assisted Extraction, Structural Characterization, Chain Conformation, and Biological Activities of a Pectic-Polysaccharide from Okra (Abelmoschus esculentus). Molecules 2020, 25, 1155. [CrossRef] [PubMed]

15. International Diabetes Federation (IDF). International Diabetes Atlas, 8th ed.; International Diabetes Federation: Brussels, Belgium, 2017; ISBN 78-2-930229-87-4. Available online: www.diabetesatlas.org (accessed on 30 March 2021).

16. Hullatti, K.; Telagari, M. In-vitro $\alpha$-amylase and $\alpha$-glucosidase inhibitory activity of Adiantum caudatum Linn. and Celosia argentea Linn. extracts and fractions. Indian J. Pharmacol. 2015, 47, 425-429. [CrossRef] [PubMed]

17. Bhatia, A.; Singh, B.; Arora, R.; Arora, S. In vitro evaluation of the $\alpha$-glucosidase inhibitory potential of methanolic extracts of traditionally used antidiabetic plants. BMC Complementary Altern. Med. 2019, 19, 1-9. [CrossRef]

18. Ashraf, S.A.; ElKhalifa, A.E.O.; Siddiqui, A.J.; Patel, M.; Awadelkareem, A.M.; Snoussi, M.; Ashraf, M.S.; Adnan, M.; Hadi, S. Cordycepin for Health and Wellbeing: A Potent Bioactive Metabolite of an Entomopathogenic Cordyceps Medicinal Fungus and Its Nutraceutical and Therapeutic Potential. Molecules 2020, 25, 2735. [CrossRef]

19. Siddiqui, A.J.; Danciu, C.; Ashraf, S.A.; Moin, A.; Singh, R.; Alreshidi, M.; Patel, M.; Jahan, S.; Kumar, S.; Alkhinjar, M.I.M.; et al. Plants-Derived Biomolecules as Potent Antiviral Phytomedicines: New Insights on Ethnobotanical Evidences against Coronaviruses. Plants 2020, 9, 1244. [CrossRef]

20. Noumi, E.; Snoussi, M.; Anouar, E.; Alreshidi, M.; Veettil, V.; Elkahoui, S.; Adnan, M.; Patel, M.; Kadri, A.; Aouadi, K.; et al. HR-LCMS-Based Metabolite Profiling, Antioxidant, and Anticancer Properties of Teucrium polium L. Methanolic Extract: Computational and In Vitro Study. Antioxidants 2020, 9, 1089. [CrossRef]

21. Reddy, M.N.; Adnan, M.; Alreshidi, M.M.; Saeed, M.; Patel, M. Evaluation of Anticancer, Antibacterial and Antioxidant Properties of a Medicinally Treasured Fern Tectaria coadunata with its Phytoconstituents Analysis by HR-LCMS. Anti Cancer Agents Med. Chem. 2020, 20, 1845-1856. [CrossRef]

22. Durazzo, A.; Lucarini, M.; Novellino, E.; Souto, E.B.; Daliu, P.; Santini, A. Abelmoschus esculentus (L.): Bioactive Components' Beneficial Properties-Focused on Antidiabetic Role-For Sustainable Health Applications. Molecules 2018, 24, 38. [CrossRef]

23. Ahmed, M.A.; Holz, M.; Woche, S.K.; Bachmann, J.; Carminati, A. Effect of soil drying on mucilage exudation and its water repellency: A new method to collect mucilage. J. Plant Nutr. Soil Sci. 2015, 178, 821-824. [CrossRef]

24. Emeje, M.; Isimi, C.; Byrn, S.; Fortunak, J.; Kunle, O.; Ofoefule, S. Extraction and Physicochemical Characterization of a New Polysaccharide Obtained from the Fresh Fruits of Abelmoschus Esculentus. Iran. J. Pharm. Res. IJPR 2011, 10, $237-246$.

25. Lengsfeld, C.; Titgemeyer, F.; Faller, G.; Hensel, A. Glycosylated Compounds from Okra Inhibit Adhesion of Helicobacter pylori to Human Gastric Mucosa. J. Agric. Food Chem. 2004, 52, 1495-1503. [CrossRef]

26. Kong, J.; Yu, S. Fourier Transform Infrared Spectroscopic Analysis of Protein Secondary Structures. Acta Biochim. Biophys. Sin. 2007, 39, 549-559. [CrossRef]

27. Haq, M.A.; Alam Jafri, F.; Hasnain, A. Effects of plasticizers on sorption and optical properties of gum cordia based edible film. J. Food Sci. Technol. 2016, 53, 2606-2613. [CrossRef]

28. Archana, G.; Sabina, K.; Babuskin, S.; Radhakrishnan, K.; Fayidh, M.A.; Babu, P.A.S.; Sivarajan, M.; Sukumar, M. Preparation and characterization of mucilage polysaccharide for biomedical applications. Carbohydr. Polym. 2013, 98, 89-94. [CrossRef]

29. Zaharuddin, N.D.; Noordin, M.I.; Kadivar, A. The Use of Hibiscus esculentus (Okra) Gum in Sustaining the Release of Propranolol Hydrochloride in a Solid Oral Dosage Form. BioMed Res. Int. 2014, 2014, 1-8. [CrossRef]

30. Antoniou, J.; Liu, F.; Majeed, H.; Qazi, H.J.; Zhong, F. Physicochemical and thermomechanical characterization of tara gum edible films: Effect of polyols as plasticizers. Carbohydr. Polym. 2014, 111, 359-365. [CrossRef]

31. Kaur, G.; Singh, D.; Brar, V. Bioadhesive okra polymer based buccal patches as platform for controlled drug delivery. Int. J. Biol. Macromol. 2014, 70, 408-419. [CrossRef]

32. Lee, C.S.; Chong, M.F.; Robinson, J.; Binner, E. Optimisation of extraction and sludge dewatering efficiencies of bio-flocculants extracted from Abelmoschus esculentus (okra). J. Environ. Manag. 2015, 157, 320-325. [CrossRef]

33. Kale, P. Extraction and Characterization of Okra Mucilage as a Pharmaceutical Aid. Int. J. Sci. Dev. Res. $2020,5,189-193$.

34. Rizwan, M.; Yahya, R.; Hassan, A.; Yar, M.; Azzahari, A.D.; Selvanathan, V.; Sonsudin, F.; Abouloula, C.N. pH Sensitive Hydrogels in Drug Delivery: Brief History, Properties, Swelling, and Release Mechanism, Material Selection and Applications. Polymers 2017, 9, 137. [CrossRef]

35. Soetan, K.O.C.; Oyewole, O. The importance of mineral elements for humans, domestic animals and plants: A review. Afr. J. Food Sci. 2010, 4, 200-222.

36. Hanif, R.I.Z.; Iqbal, M.; Hanif, S.; Rasheed, M. Use of vegetables as nutritional food: Role in human health. J. Agric. Biol. Sci. 2006, $1,18-22$.

37. Oka, Y.; Udaka, K.; Tsuboi, A.; Elisseeva, O.A.; Ogawa, H.; Aozasa, K.; Kishimoto, T.; Sugiyama, H. Cancer Immunotherapy Targeting Wilms' Tumor Gene WT1 Product. J. Immunol. 2000, 164, 1873-1880. [CrossRef] 
38. Chitturi, R.; Baddam, V.R.; Prasad, L.; Prashanth, L.; Kattapagari, K. A review on role of essential trace elements in health and disease. J. Dr. NTR Univ. Health Sci. 2015, 4, 75. [CrossRef]

39. National Research Council (US) Committee on Diet and Health. Diet and Health: Implications for Reducing Chronic Disease Risk; National Academies Press: Washington, DC, USA, 1989; ISBN 978-0-309-07474-2.

40. Gasche, C.; Lomer, M.; Cavill, I.; Weiss, G. Iron, anaemia, and inflammatory bowel diseases. Gut 2004, 53, 1190-1197. [CrossRef]

41. Chasapis, C.T.; Ntoupa, P.-S.A.; Spiliopoulou, C.A.; Stefanidou, M.E. Recent aspects of the effects of zinc on human health. Arch. Toxicol. 2020, 94, 1443-1460. [CrossRef]

42. Jabeen, S.; Shah, M.; Khan, S.; Hayat, M.Q. Determination of major and trace elements in ten important folk therapeutic plants of Haripur basin, Pakistan. J. Med. Plants Res. 2010, 4, 559-566. [CrossRef]

43. Read, S.A.; Obeid, S.; Ahlenstiel, C.; Ahlenstiel, G. The Role of Zinc in Antiviral Immunity. Adv. Nutr. 2019, 10, 696-710. [CrossRef]

44. Kardalas, E.; Paschou, S.A.; Anagnostis, P.; Muscogiuri, G.; Siasos, G.; Vryonidou, A. Hypokalemia: A clinical update. Endocr. Connect. 2018, 7, R135-R146. [CrossRef] [PubMed]

45. Ahmed, B.T.; Kumar, S.A. Antioxidant and Antidiabetic properties of Abelmoschus esculentus extract-An in vitro assay. Res. J. Biotechnol. 2016, 11, 34-41.

46. Aligita, W.; Muhsinin, S.; Susilawati, E.; Dahlia; Pratiwi, D.S.; Aprilliani, D.; Artarini, A.; Adnyana, I.K. Antidiabetic Activity of Okra (Abelmoschus esculentus L.) Fruit Extract. Rasayan J. Chem. 2019, 12, 157-167. [CrossRef]

47. Ameena, K.; Dilip, C.; Saraswathi, R.; Krishnan, P.; Sankar, C.; Simi, S. Isolation of the mucilages from Hibiscus rosasinensis linn. and Okra (Abelmoschus esculentus linn.) and studies of the binding effects of the mucilages. Asian Pac. J. Trop. Med. 2010, 3, 539-543. [CrossRef]

48. Jouki, M.; Yazdi, F.T.; Mortazavi, S.A.; Koocheki, A. Quince seed mucilage films incorporated with oregano essential oil: Physical, thermal, barrier, antioxidant and antibacterial properties. Food Hydrocoll. 2014, 36, 9-19. [CrossRef]

49. Cotrim, M.D.A.P.; Mottin, A.C.; Ayres, E. Preparation and Characterization of Okra Mucilage (Abelmoschus esculentus) Edible Films. Macromol. Symp. 2016, 367, 90-100. [CrossRef]

50. Alghamdi, A.A.; Awadelkarem, A.M.; Hossain, A.B.M.S.; Ibrahim, N.A.; Fawzi, M.; Ashraf, S.A. Nutritional Assessment of Different Date Fruits (Phoenix Dactylifera L.) Varieties Cultivated in Hail Province, Saudi Arabia. Biosci. Biotechnol. Res. Commun. 2018, 11, 263-269. [CrossRef]

51. Latimer, G.W.; AOAC International. Official Methods of Analysis; AOAC International: Rockville, MD, USA, 2016; Volume 20, ISBN 0935584870.

52. Christynal Oliviya, R.; Krishnakumari, S. Anti-diabetic activity of Abelmoschus esculentus and its nano particle-A Comparative Study. Int. J. Res. Anal. Rev. 2018, 5, 415-421.

53. Mechchate, H.; Es-Safi, I.; Louba, A.; Alqahtani, A.S.; Nasr, F.A.; Noman, O.M.; Farooq, M.; Alharbi, M.S.; Alqahtani, A.; Bari, A.; et al. In Vitro Alpha-Amylase and Alpha-Glucosidase Inhibitory Activity and In Vivo Antidiabetic Activity of Withania frutescens L. Foliar Extract. Molecules 2021, 26, 293. [CrossRef] 